\title{
A comparison on the commercial quality of some seafood on the basis of their percent edibility
}

\author{
Samya H. Mohammad \\ Department of Zoology, Faculty of Science, Port Said University, Egypt \\ e-mail: samya.mohammad@ymail.com
}

\section{ABSTRACT}

The present study aimed to investigate the meat content and edibility in the commercial cockles (Cerastoderma glaucum) and gastropods (Thais carinifera) in relation to their sizes and weights. These species are among the most exploitable seafood around the world and locally. They represent a considerable economic importance, both in terms of aquaculture and harvested aquatic resource. The present results showed a significant variation in the edibility with seasons. This variation did not correlate to the spawning activities. A positive correlation in the percentage edibility with shell dimensions was recorded in the case of $C$. glaucum. On the other hand, a negative correlation with shell dimensions was obvious in $T$. carinifera. Additionally, both species exhibited negative correlations with weights. So, it can be proved that the quality of meat was in the optimum in the largest cockle and in the moderate size of the gastropod and the meat content being dependent upon the shell dimension rather than the shell weight. Consumers can obtain this sea food with good qualities most of the year except in summer (for $C$. glaucum) and winter (for $T$. carinifera). Finally, the present study put a preliminary imagination to consumers for getting their needs from seafood with good meat content at least cost.

Keywords: Commercial quality, seafood, Cerastoderma glaucum, Thais carinifera, edibility, Suez Canal.

\section{INTRODUCTION}

Seafood shows variation in the quality of their meat. Seafood of good quality usually containslarge amounts of meat in relation to their weight. Two species, the cockle Cerastoderma glaucum and the gastropod Thais carnifera are chosen to the present study.

The cockle $C$. glaucum (Poiret, 1879) is a common bivalve, representing a wide global distribution. It reaches the northern limit of its distribution on the Atlantic coast (Leontarakis et al., 2007) and is further found in the Baltic Sea, Mediterranean Sea, Red Sea, Black Sea and the Caspian Sea and its adjacent lakes (Hummel et al. 1994 and Derbali, et al., 2012), as well as in Suez Canal of Egypt (Mohammad, 2002).C. glaucum are growing in calm waters and shallow, muddy bottoms, especially in places where fresh water mixed with sea water.

The gastropod T. carinifera (Lamark, 1822) is being enormously found in Timsah Lake. It lives attached to rock substrates in the intertidal zone. Itis widely distributed (Datta et al., 2010 and Radwan et al., 2009 a) and has an economic importance as it is one of the most edible molluscs in the Suez Canal area (Hanafy, 1996).

The present study aims to collect information on the percentage edibility with a view to assessing the quality of meat in these seafood species inhabiting Suez Canal. This may aid consumers for attaining their needs with a least cost. 


\section{MATERIALS AND METHODS}

\section{Sample collection}

The specimens were randomly sampled seasonally during 2011. Samples (846 C. glaucum and 662 T. carinifera) were collected from Timsah Lake (Lat.30 $56^{\prime} \mathrm{N}$ : Long. $32^{0} 28^{\prime}$ E), Suez Canal, Ismailia, Egypt (Fig. 1). Collection was carried out by hand dredges then shaking in sieves (for the cockles) and by diving under the water and picking up the samples by hand (for the gastropods).

\section{Laboratory analysis}

Biometric measurements (shell length, shell height and shell width) were carried out using a vernier caliper to the nearest $0.05 \mathrm{~mm}$. Weights (total weight, wet weight, shell weight and operculum weight) were determined on a top-loading digital balance (precision of $0.01 \mathrm{~g}$ ).

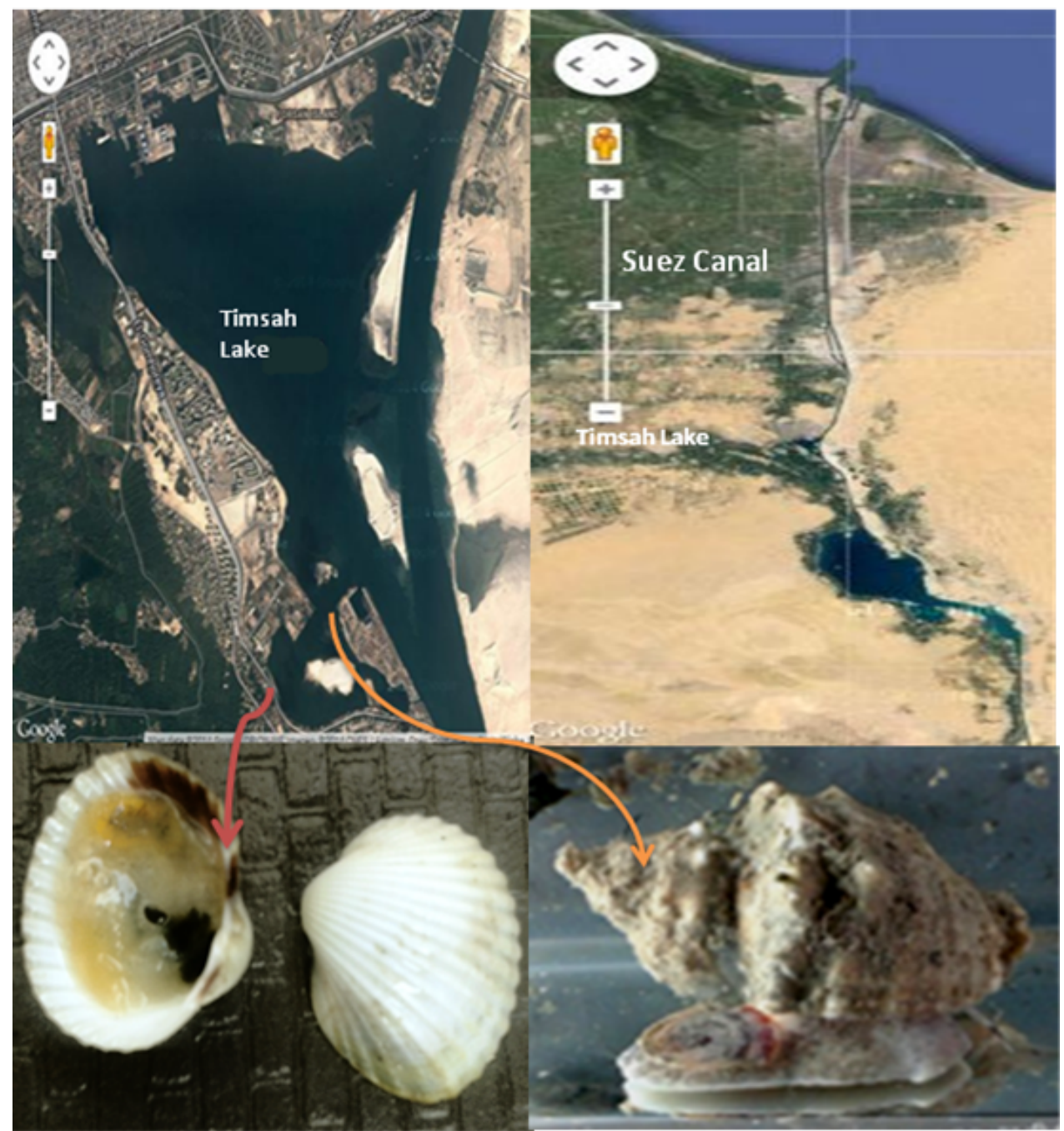

Fig. 1: (a) Landsat image for year 2004 of the Suez Canal District showing (b) locations within Timsah Lake for sampling (c) Cerastoderma glaucum and (d)Thais carinifera.

\section{Statistical analyses}

Percentage edibility was calculated using Pivot-table in Excel package. According to Venkataraman and Chari (1951) method:- 
Percentage edibility $=\frac{\text { wet meat weight }}{\text { total weight with shell }} \times 100$

Percentage of non-edibility $=100$ - percentage edibility

The seasonal variations of the studied parameters were tested by one way analysis of variance (ANOVA). Pairwise comparisons (LSD test) were made to determine which values differ significantly when a significant overall ANOVA was found $(\mathrm{p}<0.05)$. These statistical calculations were performed with the SPSS 18.0 for windows.

\section{RESULTS}

The size of the cockle C. glaucumranged between 10.50 and $35 \mathrm{~mm}$ with $21.81 \mathrm{~mm}$ mean length. The snails $T$. carinifera were in the size of 40.00 to $69.50 \mathrm{~mm}$ with a mean height of $56.98 \mathrm{~mm}$. The other descriptive statics are shown in Table (1) for both species. There was a little variation in the average percentage edibility between sexes [27.23 \& 27.61(C. glaucum) and $21.15 \& 22.40$ T. carinifera), for females and males respectively]. This variation was not significant $(\mathrm{p}<0.05)$. Hence the data was pooled and graphed.

Table 1: Descriptive statistics of some measurements $(\mathrm{mm})$ and weights $(\mathrm{g})$ of the studied species

\begin{tabular}{|c|c|c|c|c|c|c|}
\hline Species & $\begin{array}{c}\text { Measurements and } \\
\text { weights }\end{array}$ & $\mathbf{N}$ & Minimum & Maximum & Mean & Std. Deviation \\
\hline $\begin{array}{c}\text { Cerastoderma } \\
\text { glaucum }\end{array}$ & Shell length & 846 & 10.50 & 35.00 & 21.81 & 4.20 \\
\hline & Shell height & 846 & 11.40 & 29.90 & 19.28 & 3.35 \\
\hline & Shell width & 846 & 1.72 & 27.90 & 15.10 & 2.92 \\
\hline & Total weight & 846 & .76 & 13.64 & 3.63 & 1.86 \\
\hline & Soft weight & 846 & .01 & 3.95 & .94 & .54 \\
\hline & Shell weight & 846 & .58 & 11.73 & 2.69 & 1.39 \\
\hline Thais carinifera & Shell height & 662 & 40.00 & 69.50 & 56.98 & 5.67 \\
\hline & Shell width & 662 & 25.00 & 58.00 & 39.18 & 4.36 \\
\hline & Operculum weight & 662 & .10 & 1.10 & .23 & .13 \\
\hline & Total weight & 662 & 9.55 & 77.70 & 40.02 & 2.99 \\
\hline & Soft weight & 662 & 3.03 & 32.20 & 11.31 & 3.71 \\
\hline & Shell weight & 662 & 3.28 & 69.00 & 28.86 & 1.34 \\
\hline
\end{tabular}

\section{C. glaucum}

Fig. (2) reveals that the fall in summer (21.91) was more obvious than in other seasons and the highest value (29.53) was recorded in winter. Highly significant variations were recorded between different seasons except that between autumn and spring $(\mathrm{p}=0.82)$ as shown in Table (2). Generally, there was a trend to increase in the percent edibility in the largest cockles. Table (3) also shows moderate $\left(\mathrm{R}^{2}=0.68\right)$ to strong $\left(\mathrm{R}^{2}=0.72 \& 0.91\right)$ correlation between percent edibility and shell dimensions (shell height, shell width and shell length, respectively). Reversely, shell weight exhibited negative and weak correlation $\left(b=-0.73 \& R^{2}=0.4\right)$ with the in the percent edibility.

\section{Thais carinifera}

Seasonal variation in the percentedibility of $T$. cariniferawas highly significant $(\mathrm{p}<0.01)$ except that between summer and autumn $(\mathrm{p}=0.54)$ as recorded in Table (2). 

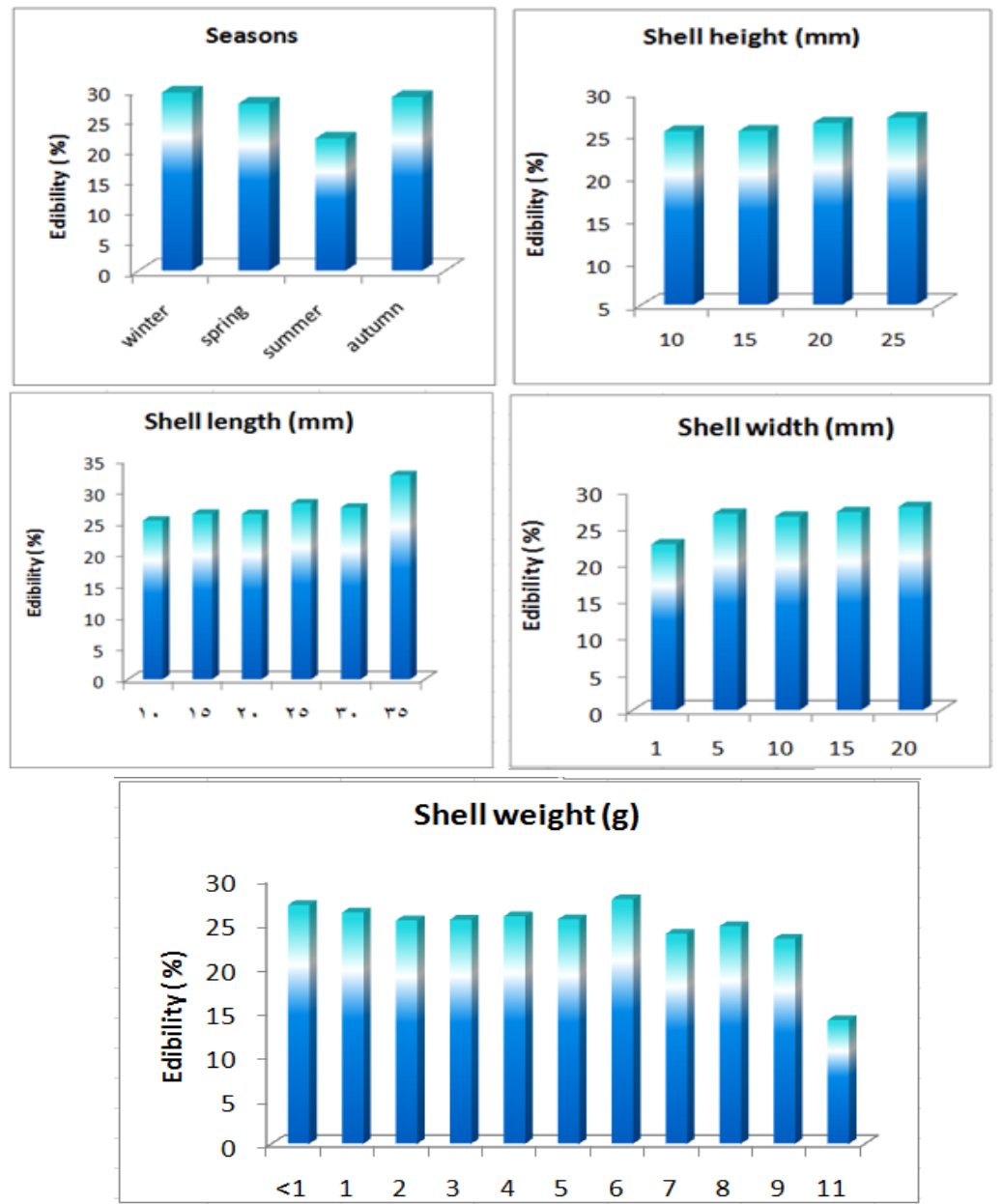

Fig. 2: Percent edibilty of Cerastoderma glaucum with different seasons, shell dimensions and shell weights.

Table 2: Multiple comparisons in the percent edibility of the studied species between different seasons

\begin{tabular}{|c|c|c|c|c|}
\hline Species & \multicolumn{2}{|c|}{ Season } & Std. Error & Sig. \\
\hline \multirow{12}{*}{ Cerastoderma glaucum } & Autumn & spring & .52 & .82 \\
\hline & & summer & .55 & .00 \\
\hline & & winter & .60 & .00 \\
\hline & spring & Autumn & .52 & .82 \\
\hline & & summer & .46 & .00 \\
\hline & & winter & .51 & .00 \\
\hline & summer & Autumn & .55 & .00 \\
\hline & & spring & .46 & .00 \\
\hline & & winter & .55 & .00 \\
\hline & winter & Autumn & .60 & .00 \\
\hline & & spring & .51 & .00 \\
\hline & & summer & .55 & .00 \\
\hline \multirow[t]{12}{*}{ Thais carinifera } & Autumn & spring & .71 & .00 \\
\hline & & summer & .70 & .54 \\
\hline & & winter & .80 & .00 \\
\hline & spring & Autumn & .71 & .00 \\
\hline & & summer & .50 & .00 \\
\hline & & winter & .62 & .00 \\
\hline & summer & Autumn & .70 & .54 \\
\hline & & spring & .50 & .00 \\
\hline & & winter & .62 & .00 \\
\hline & winter & Autumn & .80 & .00 \\
\hline & & spring & .62 & .00 \\
\hline & & summer & .62 & .00 \\
\hline
\end{tabular}


The lowest value (24.75) was recorded in winter and the highest (30.15) was in spring (Fig. 3). A gradual increase in the edibility was noticed up to $50 \mathrm{~mm}$ shell height and $35 \mathrm{~mm}$ shell width and then it gradually declined. But a clear inversely relationship was noticed between the percent edibility and each of operculum weight and shell weight (Fig. 3 and Table 3 ).
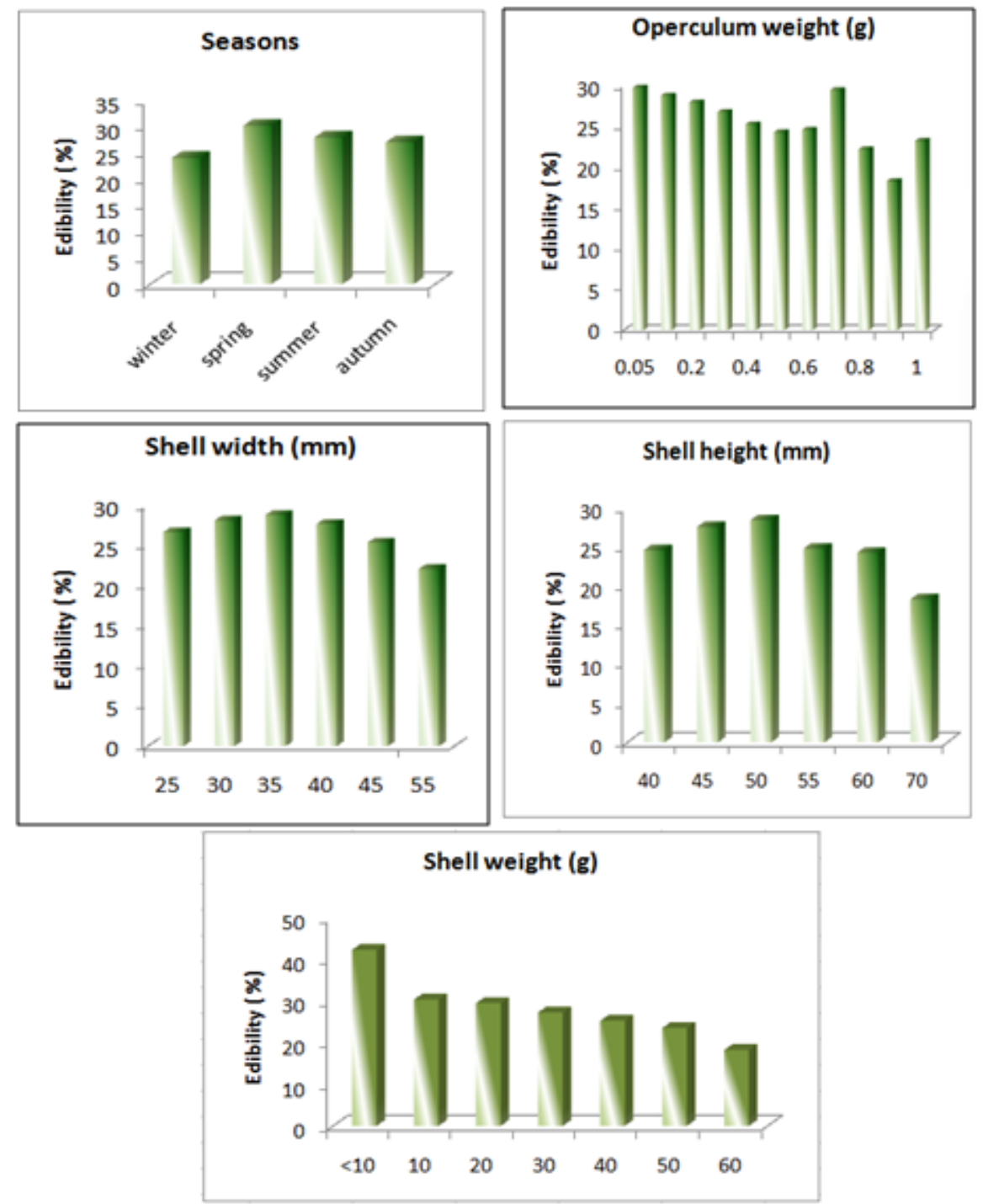

Fig. 3: Percent edibilty of Thais carinifera with different seasons, shell dimensions and shell weights.

Table 3: Regression equations and correlation coefficients of percent edibility with different shell measurements $(\mathrm{mm})$ and weights $(\mathrm{g})$ of the studied species

\begin{tabular}{|c|c|c|c|c|}
\hline Measurements and weights & \multicolumn{2}{|c|}{ Cerastoderma glaucum } & \multicolumn{2}{c|}{ Thais carinifera } \\
\hline Shell length & $\mathrm{y}=0.2341 \mathrm{x}+22.442$ & $\mathrm{R}^{2}=0.723$ & & \\
\hline Shell height & $\mathrm{y}=1.0441 \mathrm{x}+22.974$ & $\mathrm{R}^{2}=0.6772$ & $\mathrm{y}=-0.9212 \mathrm{x}+29.61$ & $\mathrm{R}^{2}=0.4949$ \\
\hline Shell width & $\mathrm{y}=0.1141 \mathrm{x}+24.05$ & $\mathrm{R}^{2}=0.9117$ & $\mathrm{y}=-0.2473 \mathrm{x}+37.823$ & $\mathrm{R}^{2}=0.5645$ \\
\hline Shell weight & $\mathrm{y}=-0.7311 \mathrm{x}+28.805$ & $\mathrm{R}^{2}=0.4322$ & $\mathrm{y}=-3.2156 \mathrm{x}+40.95$ & $\mathrm{R}^{2}=0.8642$ \\
\hline Operculum weight & & & $\mathrm{y}=-8.0836 \mathrm{x}+29.592$ & $\mathrm{R}^{2}=0.5586$ \\
\hline
\end{tabular}




\section{DISCUSSION}

Seasonal variation in the percent edibility was recorded in the present study. Fall in the edibility in summer (for C. glaucum) and winter (for T. carinifera) was more rapid than in other seasons. However, there was no obvious relationship with spawning activity as mentioned by many authors for other seafood (Nair \&Nair, 1987 and Durve, 1964). Seafood of the present study characterize by continuous spawning without a definite pattern (Mohammad, 2002 and Radwan et al., 2009b).So we can conclude that percent edibility did not depend upon spawning activity. That can interpret the non-significant difference that exhibited between sexes in the edibility. Alternatively, we can suggest that it depends on food availability to a large extent. The smallest edibility was recorded in two different seasons for the two studied species (summer and winter for $C$. glaucumand $T$. carinifera, respectively). The first species (C. glaucum) is filter feeding, feeds only on phytoplankton. Nassar and Hamed (2003) discussed phytoplankton standing crop in Suez bay. They said that there were two main phytoplankton peaks during spring and autumn seasons (average of 15,676 and 15,376 units $^{-1}$ respectively), whilst the phytoplankton represent only 6.419 unit $\mathrm{L}^{-1}$ in summer. This may explain the lowest edibility of C. glaucumin summer in the present study. On the other hand, the second species is cariniferous, feed on bivalves and barnacles specially Balanus sp. (Broom, 1982 and Radwan et al., 2009a). Shalla et al., (1995) studied the growth of Balanus amphitrite in Lake Timsah. They recorded the abundance of this barnacle from April to October. This agrees with our finding, as the highest percent edibility was recorded in spring followed by summer then autumn. So we can conclude that percent of edibility mainly depending on food availability.

The present study revealed that the percent edibility of $C$. glaucum depend, to a large extent, on shell dimensions and not on shell weight. This was clear from the strong correlation $\left(\mathrm{R}^{2}=0.72\right.$ and 0.91$)$ with both of the shell width and length, and the weak and negative correlation $\left(\mathrm{R}^{2}=0.4\right.$ and $\left.\mathrm{b}=-0.73\right)$ with shell weight. Accordingly, we advise the consumers to buy seafood with larger shell. Concerning the gastropod T. carinifera, it exhibited negative correlation with shell dimensions and weights. This accounted for the progressive increase in percent edibility onwards attaining the maximum in the moderate size (shell length $=50 \mathrm{~mm}$ and shell width $=35 \mathrm{~mm}$ ) after which it gradually declined. So, the results clearly indicate that the quality of the meat was in the optimum in the moderate size, and hence it is the suitable size for consumer.

Comparing percent edibility of the studied species with other popular seafood inhabiting Suez Canal (Mohammad, in preparation and Mohammad and Yusuf, in preparation) is seen in Figure (4a). It appears that percent edibility of $T$. carinifera was the lowest. We can attribute it to its shell thickness. The shell of the gastropod is heavier and hence a loss of the shell in the form of non-edibility is higher than the other sea food (Fig. 4b). On the other hand, Callista florida and Tapes decussatus achieved the highest percent edibility.

This observation supports the suitability of percent edibility in assessing the quality of the seafood. The meat volume being dependent upon the shell dimension, the larger the shell the more will be the meat in case of $C$. glaucum and the reverse is true in $T$. carinifera. The meat volume was also being dependent upon seasons. So, consumers must avoid buying C. glaucum and T. carinifera in summer and winter, respectively, and the remaining seasons are suitable for both. Finally, this study makes science in the service of the community to get their need at the lowest cost. 


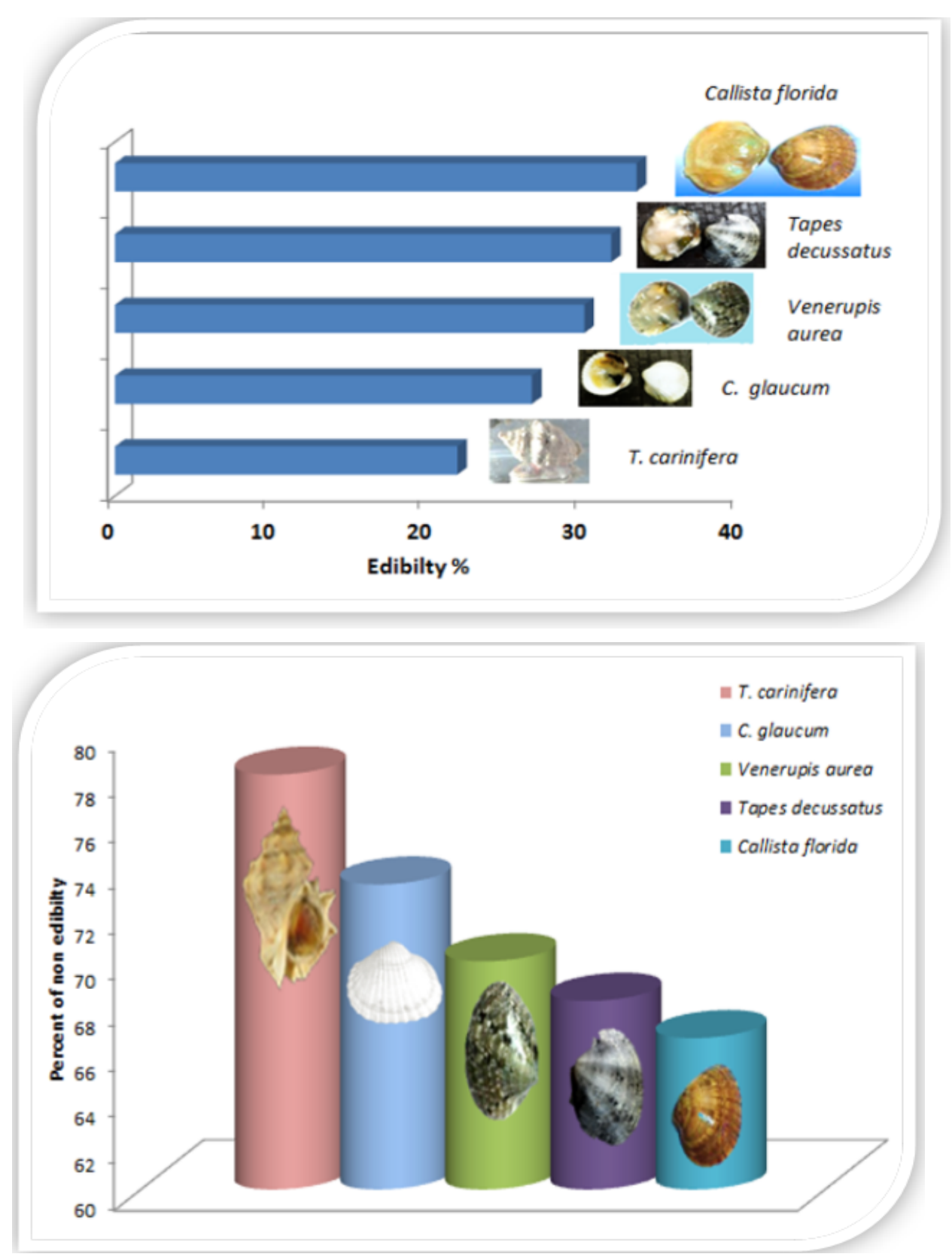

Fig.4: Percent (a) edibility and (b) non edibilty of the studied species and other seafood.

\section{ACKNOWLEDGEMENT}

The author wishes to thanks Mr. Mohammad S. and Mr. Ahmed S. for their efforts in collecting samples and data entry to the computer.

\section{REFERENCES}

Broom, M. J. (1982). A preliminary investigation into prey species preference by the tropical gastropods Naticamaculosa lamarck and Thais carinifera (lamarck). J. Mollus. Stud., 49(1): 43-52.

Datta, S.N., Chakraborty, S. K., Jaiswar, A. K. and Ziauddin, G. (2010). A comparative study on intertidal faunal biodiversityof selected beaches of Mumbai coast. J. Environm. Biol., 31(6):981-986. 
Derbali, A., Elhasni, K., Jarboui, O. and Ghorbel, M. (2012). Distribution, abundance and biological parameters of Cerastoderma glaucum (Mollusca: Bivalvia) along the Gabes coasts (Tunisia, Central Mediterranean). Acta Adriat, 53(3): 363-374.

Durve, V.S. (1964). On the percentage edibility and the index of condition "Crassostreagryphoides" (Scholtheim). J. Mar. Biol. Assoc. India 6(1): 128-134.

Govan, H. (1995). Cymatium Muricinum and Other Ranellid Gastropods: Major Predators of Cultured Tridacnid Clams. (International center of or living Aquatic Resources Management, Manila, Philippines).136 p.

Hanafy, M. H. (1996). Induction of imposex in the gastropod Thais carinifera from the Suez Canal and the Mediterranean Sea. J. Egypt. Ger. Soc. Zool. 21(D): 135-152.

Hummel H., Wolowick M. and Boggrds R.H. (1994) Genetic variability and relationships for populations of Cerastodermaedule and of the C. glaucum complex. Netherlands J. Sea Rese., 33:81-89.

Leontarakis P.K, Koutsoubas D. and Tsangridis A. (2007). Relative growth, density and population structure of the lagoon cockle, Cerastoderma glaucum (Poiret, 1879) (Mollusca: Bivalvia), from a north Aegean Sea coastal lagoon (Eratino). Proceedings of the $13^{\text {th }}$ Panhellenic Ichtyhologists Conference, Lesvos: 205208. 2.

Mohammad, S. H. (2002). Ecological and biological studies on the bivalves, Cerastoderma glaucum and Papyridea papyracea, in Lake Timsah, Suez Canal. $\mathrm{Ph}$. D. Thesis, Faculty of Science, Suez Canal University, Ismailia, Egypt.

Mohammad, S. H. (in preparation). Percent edibility of the clams Tapes decussatus and Venerupisaurea in Suez Canal, Egypt.

Mohammad, S. H. and Yusuf, M. (2015). Proximate evaluation of some economical seafood as a human diet and as an alternative prospective valuable of fish meal. J. Fish. Aquat. Sci., (in press)

Nair, N.U. and Nair, N.B. (1987). Condition index and percentage edibility of Crassosstrea madrasensis (Preston) inhabiting the cochin Harbour. Fish. Technol., 24: 15-21.

Nassar, M. Z. and Hamed, M. A. (2003). Phytoplankton standing crop and species diversity in relation to some water characteristics of Suez bay (Red Sea), Egypt. Egypt J. Aquat. Biol \& Fish., 7(3):25 - 48.

Radwan, N. A., Mohammad, S. H., Mohammed, S. Z. and Yaseen, A. E. (2009 a). Biometric studies on Thais carinifera in Lake Timsah "Suez Canal". CATRINA, 4(1): 31-37.

Radwan, N. A., Mohammad, S. H., Mohammed, S. Z., and Yaseen, A. E. (2009 b). "Reproduction and gonad development of gastropod Thais carinifera in Lake Timsah, Suez Canal, Egypt".Egypt J. Aquat. Biol. \& Fish. 13(2): 53-67

Shalla, S.H. A., Ghobashy, A. F. A. and Hartnoll, R. G. (1995). Studies on the Barnacle Balanus amphitrite Darwin, 1854 (Cirripedia) from Lake Timsah in the Suez Canal. Crustaceana, 68(4): 503-517.

Venkataraman R. and Chari S. D. T. (1951). Studies on oysters and clamsbiochemical variations. Indian J. Med. Rese., 39:533-541. 


\section{ARABIC SUMMARY}

مقارنة على الجودة التجارية لبعض المأكولات البحرية على أساس النسبه المئوية للأجزاء الصالحة للأكل

$$
\text { قسم علم الحيو ان - كلية العلوم - جامعة محند بورسعيد - مصر. }
$$

تهدف الدراسة الحاليه إلى تقدير محتوى اللحوم و الصلاحية للأكل في الأصداف البحرية التجارية (Cerastoderma glaucum)

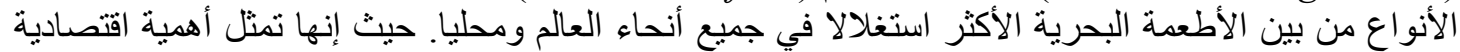

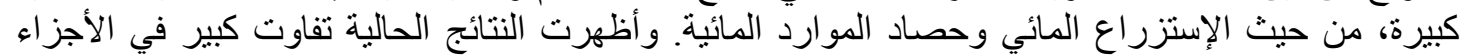

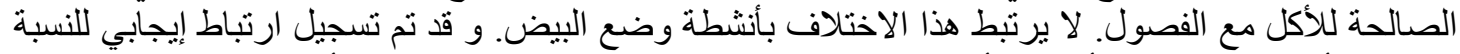

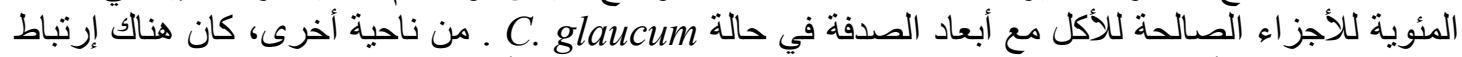

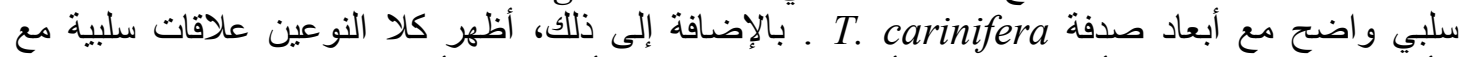

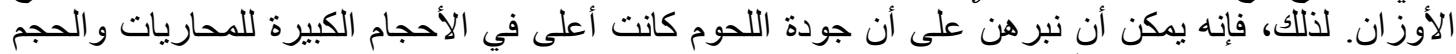

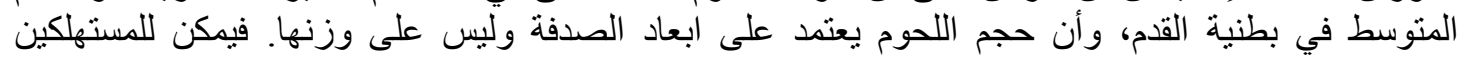

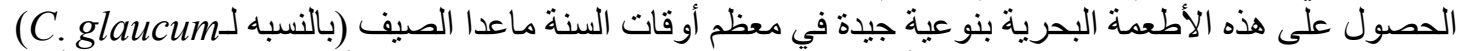

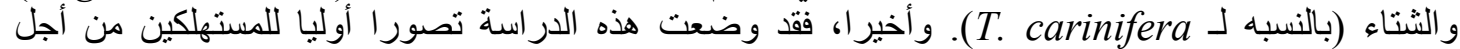
الحصول على احتياجاتهم من الأطعمة البحرية بمحتوى جيد من اللحوم وبأقل تكلفة ممكنة. 